\title{
Benefits and risks of fish consumption for the human health
}

\author{
Beneficios e riscos do consumo de \\ peixes para a saúde humana
}

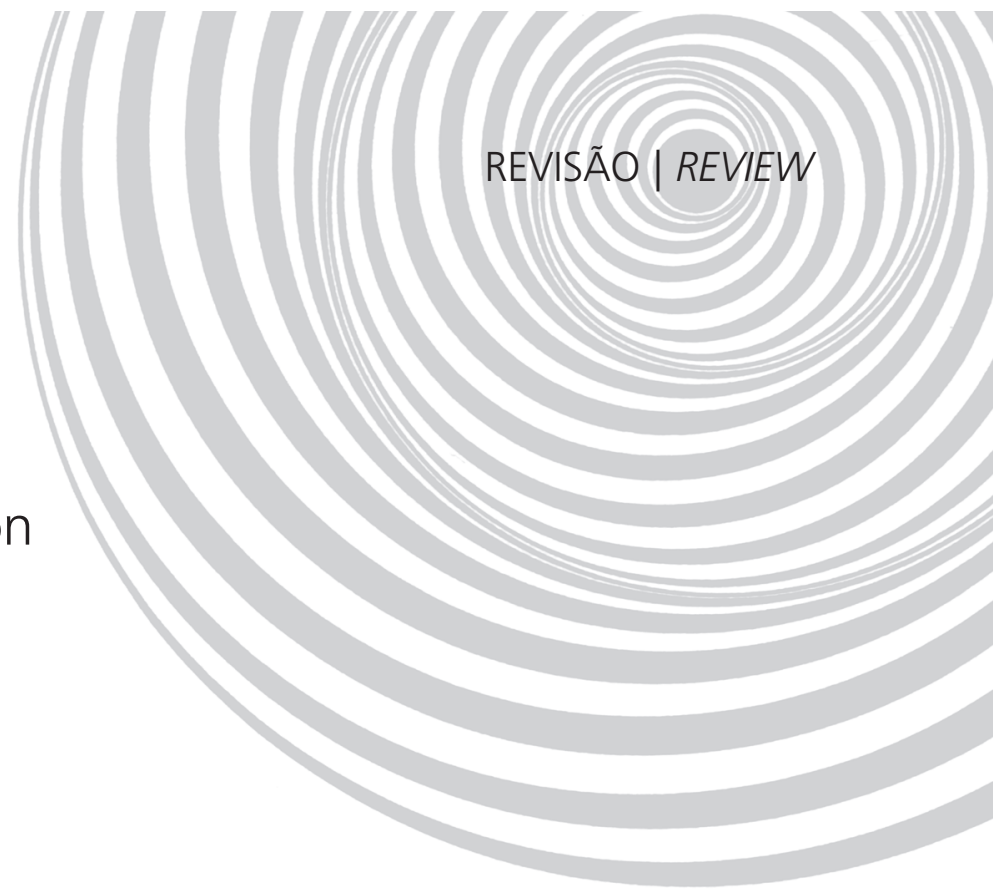

\author{
Ana Carolina FERNANDES ${ }^{1}$ \\ Caroline Opolski MEDEIROS ${ }^{1}$ \\ Greyce Luci BERNARDO' \\ Michele Vieira EBONE ${ }^{1}$ \\ Patrícia Faria DI PIETRO' \\ Maria Alice Altenburg de ASSIS ${ }^{1}$ \\ Francisco de Assis Guedes de VASCONCELOS'
}

\section{A B S T R A C T}

The article aimed at identifying and discussing scientific evidences on the benefits and risks of fish consumption the human health. There was a systematic survey for articles published from 2003 and May 2011, at the MedLine, Scopus, SciELO, Lilacs and Google Scholar databases. The key words used were: fish, food intake, omega-3 fatty acids, fatty fish, benefits, risk, and consumption. The search produced 12,632 articles, 25 eligible cohort studies on possible benefits, 61 on risks and 10 studies that assessed the "risk/benefit" relation. Of the 25 works, 14 suggested a preventive effect of fish consumption related to cardiovascular diseases, depression, cataract and some types of cancer. Evidences of a relation between exposure to mercury and an increase in the risk of neurological disorders, but not of cardiovascular diseases, were also found. Given the importance of fish consumption, its possible risks and the lack of Brazilian studies on the topic, it is important to conduct more longitudinal studies that assess both the benefits and risks of fish consumption for the human health. We also emphasize the need for policies to reduce exposure of fish and seafood to mercury and other contaminants.

Indexing terms: Fishs. Food consumption. Health. Risk.

\section{R E S U M O}

O artigo objetivou identificar e discutir evidências científicas sobre benefícios e riscos do consumo de peixes para a saúde humana. Realizou-se uma busca de artigos publicados entre 2003 e maio de 2011, nas bases de

\footnotetext{
1 Universidade Federal de Santa Catarina, Centro de Ciências da Saúde, Departamento de Nutrição, Programa de Pós-Graduação em Nutrição. Campus Trindade, s/n., 88010-970, Florianópolis, SC, Brasil. Correspondence to/Correspondência para: FAG VASCONCELOS. E-mail:<fguedes@ccs.ufsc.br>.
} 
284 AC FERNANDES et al.

dados MedLine, Scopus, SciELO, Lilacs e Google acadêmico. Utilizaram-se as palavras chaves: fish, food intake, omega-3 fatty acids, fatty fish, benefits, risk, consumption. Encontraram-se 12.632 artigos, sendo elegíveis 25 estudos de coorte que investigaram possíveis benefícios, 61 sobre riscos e 10 estudos que avaliam a relação "risco/benefício". Dentre os 25 trabalhos, 14 sugeriram efeito protetor do consumo de peixes, relacionado a doenças cardiovasculares, depressão, catarata e alguns tipos de câncer. Foram encontradas evidências de relação entre exposição ao mercúrio e aumento do risco de distúrbios neurológicos, mas não do risco de doenças cardiovasculares. Tendo em vista a importância do consumo de peixes e seus possíveis riscos, bem como a escassez de pesquisas nacionais sobre o tema, observa-se a relevância de se realizarem mais estudos longitudinais que aliem a avaliação dos benefícios e riscos do seu consumo para a saúde humana. Ressalta-se também a necessidade de políticas para redução da exposição de peixes e frutos do mar ao mercúrio e outros contaminantes.

Termos de indexação: Peixes. Consumo de alimentos. Saúde. Risco.

\section{INTRODUCTION}

Fishes are rich in essential fatty acids, as well as in iron, vitamin $B_{12}$ and calcium. Fish consumption is recommended by The American Cancer Society and the American Heart Association $(\mathrm{AHA})$ at least two times a week ${ }^{1,2}$.

Brazil has great potential for fish farming due to its extensive maritime coast and continental waters, together with the possibility of consumption of great variety of species ${ }^{2}$. Not with standing that, fish consumption in Brazil dropped considerably in recent years ${ }^{3,4}$.

Some studies have demonstrated the health benefits of fish consumption thanks to the correlation between omega-3 fatty acids and a decrease in the incidence of coronary heart diseases ${ }^{5-10}$, depression ${ }^{11,12}$, stroke ${ }^{13}$, blood pressure $^{5,14}$, glycemic index ${ }^{14}$, triglycerides ${ }^{5}$, cancer ${ }^{15,16}$ and others. On the other hand, researches could also quantify levels of fish contamination in 17 fish and check possible risks linked to its consumption, such as contamination by heavy metals, organochlorine pollutants and dioxins $^{17-20}$.

With the incentive to fish consumption and a current discussion on its benefits and risks ${ }^{21,22}$, seconded by a lack of scientific studies with clear conclusions about contamination, it is imperative that literature about risks and benefits of fish consumption is reviewed, especially in Brazil. Moreover, in the searches performed, no critical reviews on the subject were found. Therefore, this article aimed at identifying and discussing scientific evidences on the benefits and risks of fish consumption for the human health.

\section{METHODS}

The study was designed to answer a guiding question: what are the scientific evidences on benefits and risks of fish consumption for the human health? The methodology adopted followed the basic procedures recommended for studies of literature on systematic reviews ${ }^{23-25}$. In other words, systematic methods were used to critically identify, select and discuss articles published on the theme investigated and related objectives, materials and methods, as well as results observed, with drawing of conclusions on the corresponding state-of-the-art or available scientific knowledge ${ }^{23-25}$.

A systematic search to capture scientific articles published was accomplished in the period between January 2003 and May 2011, in the MedLine (National Library of Medicine), Scopus, SciELO (Scientific Electronic Library Online), Lilacs (Caribbean Latin American Literature and in Sciences of the Health) electronic databases and in Google Scholars. The key words used were: fish in combination with food intake (dietary consumption), omega-3 fatty acids, fatty fish, benefits, risk, consumption.

The criteria to include articles, defined prior to the systematic survey on literature were: a) articles discussing the association between fish 
consumption and health benefits; b) articles discussing the association between omega- 3 fatty acids consumption and health benefits; c) articles discussing the relation between fish consumption and risks to the health; d) articles discussing the relation between consumption of contaminated fish and risks to the health; e) articles on human beings; and f) articles published in the Portuguese, English and Spanish languages. The criteria to exclude articles were: a) articles discussing the association between fish oil consumption and health benefits; b) studies on fish oil and omega3 fatty acids supplements; c) articles whose discussion and/or objectives did not include fish consumption assessments; $d$ ) articles of literature reviews; e) studies on validation of questionnaires; f) studies on software development; g) articles with the same data sources (same study population); h) articles with children or pregnant women; i) articles with incomplete texts even after request to authors through electronic and institutional addresses available in the publications.

Considering all the electronic databases investigated, 12,632 articles were found. After reading of headings and abstracts, studies with no relation with the subject of this review and/or of similar nature were discarded. Initially, 385 articles related to possible benefits and risks of fish consumption were selected for a preliminary analysis. Among which, 152 articles met the right criteria for inclusion.

Of the 152 articles selected for analysis, 81 were related to the possible benefits of fish consumption for the human health; 61 discussed consumption of contaminated fish and its possible risks for the human health; and 10 assessed, simultaneously, the relation "risk/benefit" of fish consumption for the human health. Therefore, the investigation presented the results ahead with the following analysis criteria for the initial grouping of the 152 studies selected: articles related to "benefits", articles related to "risks" and articles related both "risks" and "benefits" of fish consumption for the human health.
After comparative analysis of the 152 studies selected, 25 of them referring to cohort studies about the benefits of fish consumption were selected and the remaining ones discarded for bearing investigations of another methodological nature. For the critical analysis of these 25 articles, it was established a descriptive script in accordance with proposals by Moher et al. ${ }^{23}$ and von Elm et al. ${ }^{25}$, where each article selected should be analyzed in relation to its objectives, materials and methods, results and conclusions, displaying a synthesis of the available scientific knowledge investigated on the theme. These 25 articles were characterized according to the following criteria for analysis: year of publication; place of research; size and sample characteristics; analyzed variables; type of statistical analysis of data; and results, including stratification or cut-off point for amount and frequency of fish consumption (Attached).

Just one cohort article on possible risks of fish consumption for the human health was selected. So, as most researches that included risks were observational studies of cross-sectional nature and it was not possible to infer a causal relationship, studies on possible risks or risks/ benefits of fish consumption for the human health were analyzed separately.

Attention must be called to absence of conflict of interests in the study design.

\section{RESULTS AND DISCUSSION}

\section{General characteristics of studies}

The 25 articles on benefits and risks associated to fish consumption investigated and based on cohort studies that attended the inclusion criteria were published in the period from $1 / 1 / 2003$ to $31 / 5 / 201$. Of these, 2 were published in $2003^{9,15}, 5$ in $2004^{6,8,12,26,27}, 3$ in $2005^{13,28,29}, 5$ in $2006^{7,30-33}, 2$ in $2007^{2,11,34}$ in $2008^{4,10,16}$ in $2010^{35-38}$ and 2 in $2011^{39,40}$. Most of them was performed in the Unites States of America (USA) $6,9,10,13,15,26,29,32,35,37$ (40\%), then 
comes Sweden ${ }^{16,38,39}$ (12\%), Finland ${ }^{12,27}$, Holland ${ }^{8,30}$, Norway ${ }^{31,34}$, Japan $^{7,40}$ and Denmark ${ }^{28,36}$ (8\% each), and Spain ${ }^{11}$ and England ${ }^{33}$ (4\% each one) (Attached).

Regarding size and the characteristics of the investigated samples, there were variations from $229^{6}$ to $310671^{31}$ individuals, where, in 12 studies, they consisted of men and women ${ }^{7,8,10-}$ $13,20,28,30,36,40$, in 10 only women $6,16,26,29,31,34,35,37-39$ and in three, only men 15,27,34. Ages ranged between 25 and 83 years old, where 15 studies included adults and older people $8,10,11,15,16,26-34,39,40$, 3 only adults ${ }^{7,12}$ and 3 only older people e,9,13 $^{6,1}$ (Attached).

Of the pathologies investigated, 13 studies assessed the association between fish consumption and cardiovascular diseases (ischemic heart disease, unspecified cardiovascular diseases, atherosclerosis progression, atrial fibrillation, arrhythmia, stroke, heart attack and venous thromboembolism) 6,7,9,10,13,26,28,30,33,35-37,39; 6 had analyzes on distinct types of cancer (not specified, prostate, breast, colon and renal cell) ${ }^{15,16,26,31,32,34}$; 5 had some psychological and/ or neurological disorders (depression, mental disorders, cognitive function, psychotic symptoms, suicide risk) $)^{8,11,12,27,38,40}$, and one, cataract $^{29}$ (Attached).

Regarding statistics, 9 articles ${ }^{6,7,9,11,13,16,26,29,32}$ used more than one type of analysis. Thus, it was observed that 14 studies $^{9,13,16,26,27,30-36,39,40}$ used survival analysis methods, with the Cox proportional risk model as the main model; one of them also used the Kaplan-Meier survival probability ${ }^{13}$. Nine studies used the regression analysis $8,11,12,15,26,37-40$ and 7 used correlation coefficients (Pearson or Spearman) 6,7,10,28,29,32,40. The odds ratio test ${ }^{9,13}$ and the covariance analysis ${ }^{6,26}$ were applied in two studies each. Also, the $t$ test and the chi-squared test ${ }^{6}$, the linear trend $^{11}$ and the Person-time ${ }^{16}$ were applied in a study each (Attached).

In the analysis of dietary methods, it was observed that 21 studies used semi-quantitative food frequency questionnaires ${ }^{6-11,13,15,16,26-34,36,37,40 . ~}$
In 7 studies, the questionnaire was sent by mail to the participants $8,11,12,15,16,26,34$; in the others, it was delivered in person or applied by the interviewer. The amount of items referring to fish consumption in the questionnaires varied depending on the study from 1 to 19 items analyzed. Not all studies mentioned the number of items included in the questionnaire of dietary frequency or how many of them referred to fish consumption. It was observed there was a validation of dietary methods in $20^{6-11,13,15,16,27-32,34-38}$ of the articles analyzed (Attached).

Regarding studies main results, 14 (56\%) displayed a beneficial relation between fish consumption and lower risk of prostate ${ }^{15}$ and renal cell cancer ${ }^{16}$, of death by ischemic heart disease ${ }^{9}$ and by heart failure ${ }^{35}$, of myocardial heart attack and non-fatal coronary events ${ }^{7}$, of acute coronary syndrome $^{36}$, of venous thromboembolism ${ }^{10}$, of atherosclerosis progression ${ }^{6}$, of stroke ${ }^{13,39}$, depression ${ }^{12}$, cognitive function damages ${ }^{8}$, psychotic symptoms ${ }^{38}$ and cataract $^{29}$. However, 11 studies (44\%) could not find any associations with cancer in general (not specified) ${ }^{26}$, colon $^{34}$, prostate ${ }^{32}$ and breast ${ }^{31}$ cancer; with stroke ${ }^{26,33}$; with atrial fibrillation 26,28,30,37; with arrhythmia26, 28; with depression ${ }^{27}$; with risk of suicide ${ }^{40}$ and with mental disorders in general ${ }^{11}$ (Attached).

An important consideration is that in just two of the studies analyzed ${ }^{9,13}$, both conducted in the USA, have considered the preparation methods of fish as a variable in their investigations (Attached). These articles have demonstrated that consumption of grilled or baked fish is associated with lower risk of death by ischemic heart disease or arrhythmia, if consumed more than 3 times a week, and lower risk of stroke, if consumed from 1 to 4 or more than 5 times a week. On the other hand, consumption of fried fish or fish sandwiches revealed an association with higher risk for the same diseases.

These findings follow the Food Guide for the Brazilian Population ${ }^{2}$ recommendations, which orients the population to prepare and consume food with little oil, such as baked, stewed, cooked 
or grilled dishes, and to prevent the fried ones. This guide was based on recommendations by the Global Strategy on Diet, Physical Activity and Health developed by the World Health Organization ${ }^{41}$, which recommends limiting consumption of high-energy food like fats and substituting unsaturated fats for saturated fat while also eliminating trans fatty acids.

\section{Fish consumption and heart diseases}

The relation between frequency of fish consumption and benefits for heart diseases could be found in studies on the population of USA, where it was demonstrated that a consumption frequency $\geq 1$ time a week was associated with a reduction in the progression of atherosclerosis in women that have reached menopause and reduction in esthenosis in diabetic women ${ }^{6}$; in the development of the venous thromboembolism in the 45 to 64 year old population, as well as in hospitalization and death rates due to weak heart in adult and aged women ${ }^{36}$. In Sweden, lean fish consumption of $\geq 3$ times a week reduced stroke risk in women ${ }^{39}$. In a study conducted in Denmark ${ }^{36}$, the average consumption of $\geq 7 \mathrm{~g}$ of fat fish a day was associated with lower risk of coronary syndrome in men, and in Japan ${ }^{7}$, fish consumption at 8 times a week was associated with lower risk of myocardial heart attack and non-fatal coronary disease when compared with a once-a-week consumption.

These studies demonstrate that fish consumption at least once a week can be a protective factor for heart diseases and, the higher the consumption frequency, the higher the protective effect is. The explanation for these findings can be: omega-3 fatty acids contribute to reduce the likelihood of blood clotting, and consequently, the risk of heart attacks and stroke ${ }^{7,10}$. Therefore, it is recommended the consumption of fish with high levels of omega-3 fatty acids, such as trout, salmon, tuna, halibut, swordfish and mackerel, to prevent heart diseases, 2 to 3 times a week ${ }^{42}$.
On the other hand, studies found no associations between distinct ranges of portions/ frequency of fish consumption and any reduction in the risks of atrial fibrillation or arrhythmia $(<2$ times/week against $\geq 2$ times/week $)^{28}$, incidence of atrial fibrillation ( 15g/day30 and $37 \sim 18 \mathrm{~g} /$ day), of stroke $(<1,1-2 \text { and }>2 \text { portions/week })^{33}$ or of death by heart diseases ( $<0,5$ to $\geq 2,5$ portions/ week $)^{26}$. It must be highlighted that two ${ }^{28,37}$ of these are among the five studies ${ }^{7,28,35-37}$ on cardiovascular benefits with the largest samples investigated. And concerning the other three, two revealed beneficial only for $m^{36}{ }^{36}$ or only for women ${ }^{35}$. Therefore, it stands out that an ample sampling may, perhaps, lead to a wider variety of life styles and confusion factors, as well as evidence differences inherent to the sexes, with the possibility of a reduced association with the benefits of fish consumption.

It must also be mentioned that the lack of specification on how fish is prepared may take to a misleading conclusion about the benefits of its consumption in heart diseases prevention. When this specification is not investigated, results indicating no benefits may have been caused by the preparation method and not by fish consumption.

\section{Fish consumption and cancer}

A study conducted in the USA ${ }^{15}$ reported that a fish consumption frequency higher than 3 times a week was associated with a reduction in the risk of prostate cancer in men. Myint et al. ${ }^{33}$ analyzed the relation between the ingestion of Alpha-Linolenic Acid (ALA) and prostate cancer incidence, and came to the conclusion that consumption from $1.09 \mathrm{~g}$ to $1.75 \mathrm{~g} /$ day of ALA, found in foods of plant and animal origin, including fish, was not associated with a risk reduction of prostate cancer development $(p=0.76)$. It is clear that although the relation between fish consumption and prostate cancer were studied in both researches, the variables studied were different from one another, since 
Augustsson et al. ${ }^{15}$ checked a possible reduction in prostate cancer in connection with fatty acid found in seafood, whereas Myint et al..$^{33}$ have only observed this reduction in relation to ingestion of ALA.

According to a study developed by Paul Terry and published in the American Society Cancer site ${ }^{42}$, men who consumed fish less than two times a week had a higher risk of developing prostate cancer than those who consumed it more frequently (2 or more times a week).

A study conducted with 61433 women who had no previous diagnosis of cancer, with ages between 40 and 76, found an association between consumption of fatty fish, in the frequency $\geq 1$ a month, and a reduction of $74 \%$ in the risk of renal cell cancer ${ }^{16}$.

Other studies found no association between a possible beneficial relation of fish consumption and a reduction in the risk of cancer development. Folsom \& Demissie ${ }^{26}$ researched, in the USA, the relation between fish consumption and cancer incidence with risk of death by cancer in 41836 postmenopausal women, with ages between 55 and 69, initially free of Cancer and Cardiovascular Diseases (CVD). The researchers found no association between ingestion of $<0.5$ to $\geq 2.5$ portions/week of this food and cancer incidence $(p=0.49)$ or risk of death $(p=0.15)$.

Koralek et al. ${ }^{32}$ checked the association between ALA total consumption and risk of prostate cancer. Contrary to the study conducted by Myint et al. ${ }^{33}$, the researchers found no association between ALA total consumption $(1.09 \mathrm{~g}$ to $1.75 \mathrm{~g} /$ day) obtained from several dietary sources, such as fish, and risk of prostate cancer $(p=0.76)$. It is clear that, in the study of Koralek et al. ${ }^{32}$, fish was not the only source of ALA. In Norway, Engeset et al. ${ }^{31}$ found no association between consumption of $5.54 \mathrm{~g}$ to $96.77 \mathrm{~g} /$ day of fish and risk of breast cancer development. In this same country, Engeset et al. ${ }^{34}$ analyzed fish consumption in 63,914 women, with ages between 40 and 71, and found no association between consumption of $46.2 \mathrm{~g}$ to $167.2 \mathrm{~g} / \mathrm{day}$ with the relative risk of colon cancer $(p=0.14)$. Thus, it was observed that the relation between cancer prevention and fish consumption is not well established, considering that few results were found to prove such beneficial effect, even when specific nutrients, that separately seem to interfere with the appearance and development of cancer, were studied.

\section{Fish Consumption, neuropsychological disorders and cataract}

About neuropsychological disorders associated to fish consumption, a study conducted with the adult population of Finland found that a low frequency consumption (up to 1 time/month) compared with the regular consumption ( $\geq 1$ time/ week) was associated with depression in women, but not in the men ${ }^{12}$. In another study developed in that country, with 50 to 69-year-old men, was also found no association between fish consumption (average $40 \mathrm{~g} /$ day) and depression ${ }^{27}$.

A study conducted with the adult population of Spain found no association between fish consumption (36.4 to $161.9 \mathrm{~g} /$ day) and the risk to develop mental disorders ${ }^{11}$. Another study developed in Japan with 40 to 69-year-old men and women also found no evidence of reduction in suicide risk related to fish consumption (32.5 to $152.84 \mathrm{~g} /$ day $)^{40}$. Therefore, the researches abovementioned about risks of mental disorder development, depression or suicide only suggests a preventive effect in fish consumption in the incidence of depression in women.

Kalmijn et al. ${ }^{8}$ assessed the cognitive function and dietary consumption, including fish consumption. The researchers found that, in 45 to 70 year-old people, the increase omega-3 of sea origin (EPA - Eicosapentaenoic Acid Consumption and DHA - Docosahexaenoic Acid) consumption was associated with reduction in the risk of cognitive function loss (19\%). Hedelin et al. ${ }^{38}$ also found that the risk of psychotic symptoms was $53 \%$ lower in women who consumed fish 
3-4 times/week when compared to the ones who hardly consumed it.

Lu et al..$^{29}$ observed an association between fish consumption in the frequency of $\geq 3$ times a week and a lower risk (relative risk $=0.89$ ) of developing cataract in women above 45 years of age, compared to the ones who ate fish $\leq 1$ time a week (relative risk=1), $p=0.01$. It seems to be clear that fish consumption may prevent cataract, psychological disorders like depression and psychotic symptoms, and loss of the cognitive function, especially in women. However, few works approaching the issue were found suggesting a need of development of more studies to produce effective conclusions on the preventive effect of fish for such disease.

\section{Fish consumption and fish contaminants}

The cohort studies analyzed did not investigate aspects related to fish contaminants, which could be responsible for the lack of association with benefits observed in part of the studies and its possible effects on consumers' health. Therefore, itstands out that fish consumption may be beneficial to the health due to the presence of fatty acids while, at the same time, it may interfere with risk factors of some pathology, due to the presence of chemical contaminants.

In this sense, researches were conducted to quantify contaminants in fish and compare the values reported with limits recommended, as well as to find out risks involved in the consumption. Among the contaminants more largely studied, the leading ones were the heavy metals, mainly mercury, the Polychlorinated Biphenyls (PCB) and the Polybrominated Diphenyl Ethers (PBDE).

Kim \& Lee ${ }^{43}$, in a study developed with 1,790 Korean 20 to 49 year-old men and women, found a relation between fish consumption and blood levels of mercury. Benefice et al. ${ }^{44}$ reported that the increase in blood mercury levels among Amerindians living in the Bolivian Amazon, also related with fish consumption, was associated with a higher susceptibility in developing neurological disorders. .Most of the other studies that explain the risks of fish consumption are limited to identification and quantification of contaminants in varied species.

Because contaminants may bring risks to the human health, studies were conducted in order to quantify contaminants and omega-3 contents, and to compare ratios between these substances ${ }^{45,46}$. Foran et al. ${ }^{46}$ developed a riskbenefit ratio, relating cancer risk and other diseases with the cumulative exposure to organic contaminants and to the omega-3 contents present in fish. In this study, for some fish, the risk of contaminants was apparently compensated by the omega-3 fatty acid benefits to the health. Other researches revealed that salmon is the species with the highest omega- 3 ratio in relation to contaminantes ${ }^{17,45,47}$. Wennberg et al. ${ }^{48}$ found no association between omega-3 and mercury, and the risk of stroke.

However, few population-based studies were found, including cohort studies, which could meet the criteria for inclusion and which quantified fish consumption, relating the effects of omega-3 and the contaminants to the health of the population studied.

It is worth mentioning the study developed by Mozaffarian et al. ${ }^{49}$, who analyzed data of 6,854 participants of the Health Professionals Follow-up Study (HPFS) and Nurses' Health Study (NHS). It was observed that mercury concentrations were positively associated with fish consumption and high ingestion of EPA and DHA, low ingestion of saturated fats, monounsaturated fats, trans fats and cholesterol, and high ingestion of protein and polyunsaturated fats. Individuals exposed to a higher mercury concentration did not present an increased risk of cardiovascular events. Moreover, fatal associations with non-fatal myocardial heart attack, heart diseases or stroke were not observed.

Thus, evidences between exposure to mercury and an increase in the risk of heart diseases were not observed, although Benefice 
et al. ${ }^{44}$ suggest that there may be a relation with higher susceptibility of developing other diseases, such as neurological disorders.

\section{CONCLUSION}

In the review performed, it was observed that more frequent studies on fish consumption related it to potential benefits to the health of consumers. Heart diseases were the most frequently studied issue and also the ones that presented the most significant associations between health prevention and fish consumption.

Studies on risks suggested a relation between consumption of contaminated fish and cancer predisposition, heart diseases and neurotoxicity, but only cross-sectional studies suggesting them could be found instead of cohort studies that might help prove such associations.

Researches about the benefits of fish consumption were applied to similar populations as regards age, but with differences with relation to sample sizes, methods, statistical analyses and especially to results, which remain contrasting.

Besides, there were disagreements concerning the amount and frequency recommended for fish consumption in order to enjoy the benefits. However, despite the disagreements, there are national and international recommendations advising an ingestion of at least 2 times a week. Moreover, most of the studies about fish consumption is developed in the north hemisphere, and may not reflect the Brazilian reality since the fish species consumed are different as are the ways of preparation.

In view of fish consumption recommendations, especially concerning omega-3 intake, and of current discussions on fish contaminants together with the scarcity of national researches on the subject, it becomes clear the importance of a development of longitudinal studies that may integrate assessments on the benefits and on the risks of fish consumption with the human health. It is also fundamental the creation of policies to reduce fish and seafood exposure to mercury and other sources of contamination.

\section{ONTRIBUTION}

AC FERNANDES, CO MEDEIROS, GL BERNAR$D O$ and MV EBONE took part in the project design, data collection, analysis and interpretation, and in the article composition. PF DI PIETRO and MAA ASSIS took part in the accurate critical review of the intellectual content and in the final review of the version. FAG VASCONCELOS took part in the project design, article composition, accurate critical revision of the intellectual content and in the final version.

\section{REFERENCES}

1. American Heart Association. Fish and omega-3 fatty acids [Internet]. [cited 2008 May 6] [ 3 telas]. Available from: <http://www.americanheart.org/ presenter.jhtml?identifier $=4632>$.

2. Brasil. Ministério da Saúde. Guia Alimentar para a população brasileira: promovendo a alimentação saudável. Brasília: MS; 2006.

3. Food and Agriculture Organization of The United Nations. Food balance sheets [1 tela]. Rome: FAO; 2008 [ cited 2008 May 6]. Available from: <http:// faostat.fao.org/site/502/DesktopDefault.aspx? PagelD $=502>$.

4. Instituto Brasileiro de Geografia e Estatística. Pesquisa de orçamentos familiares, 2008-2009: análise do consumo alimentar pessoal do Brasil. Rio de Janeiro: IBGE; 2011.

5. Chrysohoou C, Panagiotakos DB, Pitsavos C, Skoumas J, Krinos X, Chloptsios Y, et al. Long-term fish consumption is associated with protection against arrhythmia in healthy persons in a Mediterranean region: the ATTICA study. Am J Clin Nutr. 2007; 85(5):1385-91.

6. Erkkilä AT, Lichtenstein AH, Mozaffarian D, Herrington DM. Fish intake is associated with a reduced progression of coronary artery atherosclerosis in postmenopausal women with coronary artery disease. Am J Clin Nutr. 2004; 80(3): 626-32.

7. Iso H, Kobayashi M, Ishihara J, Sasaki S, Okada K, Kita $Y$, et al. Intake of fish and n3 fatty acids and risk of coronary heart disease among Japanese: the Japan Public Health Center-Based (JPHC) - study cohort I. Circulation [Internet]. 2006 [cited 2008 
Apr 25]; 113(2):195-202. Available from: <http:// circ.ahajournals.org/cgi/content/full/113/2/195>. doi: 10.1161/CIRCULATIONAHA.105.581355.

8. Kalmijn S, van Boxtel MPJ, Ocké M, Verschuren WMM, Kromhout D, Launer LJ. Dietary intake of fatty acids and fish in relation to cognitive performance at middle age. Neurology. 2004; 62(2):275-80. doi: 10.1212/01.WNL.00001038 60.75218.A5.

9. Mozaffarian D, Lemaitre RN, Kuller LH, Burke GL, Tracy RP, Siscovick DS. Cardiac benefits of fish consumption may depend on the type of fish meal consumed the cardiovascular health study. Circulation. 2003; 107(10):1372-7. doi: 10.1161/ 01.CIR.0000055315.79177.16.

10. Steffen LM, Folsom AR, Cushman M, Jacobs, DR, Rosamond WD. Greater fish, fruit, and vegetable intakes are related to lower incidence of venous thromboembolism: the longitudinal investigation of thromboembolism etiology. Circulation [Internet]. 2008 [cited 2008 Apr 24]; 115(2):188-95 [ 9 p.] Available from: <http://www.circulationaha.org/>. doi: 10.1161/CIRCULATIONAHA.106.641688.

11. Sanchez-Villegas A, Henríquez P, Figueiras A, Ortuño F, Lahortiga F, Martínez-González M. Long chain omega-3 fatty acids intake, fish consumption and mental disorders in the SUN cohort study. Eur J Nutr. 2007; 46(6):337-46. doi: 10.1007/s00394007-0671-x.

12. Timonen M, Horrobinc D, Jokelainena J, Laitinene J, Hervaf A, Räsänen P. Fish consumption and depression: the Northern Finland 1966 birth cohort study. J Affect Disord. 2004; 82(3):447-52. doi: 1 0.1016/j.jad.2004.02.002.

13. Mozaffarian D, Longstreth WT, Lemaitre RN, Manolio TA, Kuller LH, Burke GL, et al. Fish consumption and stroke risk in elderly individuals: the cardiovascular health study. Arch Intern Med. 2005; 165(2):200-6. doi: 10.1001/archinte.165. 2.200 .

14. Neumann AICP, Martins IS, Marcopito LF, Araújo EAC. Padrões alimentares associados a fatores de risco para doenças cardiovasculares entre residentes de um município brasileiro. Pan Am J Public Health. 2007; 22(5):329-39. doi: 10.1590/S1020-4989 2007001000006.

15. Augustsson K, Michaud DS, Rimm EB, Leitzmann MF, Stampfer MJ, Willett WC, et al. A prospective study of intake of fish and marine fatty acids and prostate cancer. Cancer Epidemiol Biomarkers Prev. 2003; 12(1):64-7.

16. Wolk A, Larsson SC, Johansson JE, Ekman P. Longterm fatty fish consumption and renal cell carcinoma incidence in women. JAMA. 2006; 296(11):1371-6. doi: 10.1001/jama.296.11.1371.
17. Sioen I, Bilau M, Verdonck F, Verbeke W, Willems JL, De Henauw S, et al. Probabilistic intake assessment of polybrominated diphenyl ethers and omega-3 fatty acids through fish consumption. Mol Nutr Food Res. 2008; 52(2):250-7. doi: 10.1002/ mnfr.200700109.

18. Burger J, Gochfeld M. Heavy metals in commercial fish in New Jersey. Environ Res. 2005; 99(3):403-12. doi: 10.1016/j.envres.2005.02.001.

19. Burger J, Gochfeld M. Mercury in fish available in supermarkets in Illinois: are there regional differences. Sci Total Environ. 2006; 367(2-3):1010-6. doi: 10.1 016/j.scitotenv.2006.04.018.

20. Morgano MA, Gomes PC, Mantovani DMB, Perrone AAM, Santos TF. Níveis de mercúrio total em peixes de água doce de pisciculturas paulistas. Ciênc Tecnol Aliment. 2005; 25(2):250-3. doi: 10.1 590/S0101-20612005000200011.

21. Santerre CR. Balancing the risks and benefits of fish for sensitive populations. J Food Service. 2008; 19(4):205-12. doi: 10.1111/j.1748-0159. 2008.0 0111.x.

22. Violette $C$. Seafood: exploring benefits and risks. J Food Service. 2008; 19(4):201-4. doi: 10.1111/j.17 48-0159.2008.00116.x.

23. Moher D, Tetzlaff J, Tricco AC, Sampsom M, Altman DG. Epidemiology and reporting characteristics of systematic reviews. PLoS Med. 2007; 4(3):447-55. doi: 10.1371/journal.pmed.0040078.

24. Oliveira RS, Colaço W, Coulaud-Cunha S, Castilho SR. Revisão sistemática em fitoterapia: padronização internacional de qualidade. Rev Bras Farmacog. 2007; 17(2):272-4. doi: 10.1590/S0102-695X20 07000200023.

25. von Elm E, Altman DG, Egger M, Pocock SJ, Gotzsche PC, Vandenbroucke JP. The strengthening the report of observational studies in epidemiology (STROBE) statement: guidelines for reporting observational studies. J Clin Epidemiol. 2008; 61(4): 344-9. doi: 10.1016/j.jclinepi.2007.11.00.

26. Folsom AR, Demissie Z. Fish intake, marine omega-3 fatty acids, and mortality in a cohort of postmenopausal women. Am J Epidemiol. 2004; 160(10):1005-10. doi: 10.1093/aje/kwh307.

27. Hakkarainen R, Partonen T, Haukka J, Virtamo J, Albanes D, Lönnqvist J. Is low dietary intake of omega-3 fatty acids associated with depression? Am J Psychiatry. 2004; 161(3):567-9.

28. Frost L, Vestergaard P. N-3 Fatty acids consumed from fish and risk of atrial fibrillation or flutter: the Danish diet, cancer, and health study. Am J Clin Nutr. 2005; 81(1):50-4.

29. Lu M, Cho E, Taylor A, Hankinson SE, Willett WC, Jacques PF. Prospective study of dietary fat and risk 
of cataract extraction among US women. Am J Epidemiol. 2005; 161(10):948-59. doi: 10.1093/aje/ kwi118.

30. Brouwer IA, Heeringa J, Geleijnse JM, Zock PL, Witteman JCM. Intake of very long-chain n-3 fatty acids from fish and incidence of atrial fibrillation. The Rotterdam Study. Am Heart J. 2006; 151(4): 857-62. doi:10.1016/j.ahj.2005.07.029.

31. Engeset $D$, Alsaker $E$, Lund $E$, Welch $A$, Khaw KT, Clavel-Chapelon $\mathrm{F}$, et al. Fish consumption and breast cancer risk. The European Prospective Investigation into Cancer and Nutrition (EPIC). Int J Cancer. 2006; 119(1): 175-82. doi: 10.1002/ijc.21 819.

32. Koralek DO, Peters U, Andriole G, Reding D, Kirsh $V$, Subar A, et al. A prospective study of dietary alpha-linolenic acid and the risk of prostate cancer (United States). Cancer Causes Control. 2006; 17(6):783-91. doi: 10.1007/s10552-006-0014-x.

33. Myint PK, Welch AA, Bingham SA, Luben RN, Wareham NJ, Day NE. Habitual fish consumption and risk of incident stroke: the European Prospective Investigation into Cancer (EPIC)-Norfolk prospective population study. Public Health Nutr. 2006; 9(7):882-8. doi: 10.1017/phn2006942.

34. Engeset D, Andersen V, Hjartåker A, Lund E. Consumption of fish and risk of colon cancer in the Norwegian Women and Cancer (NOWAC) study. Br J Nutr. 2007; 98(3):576-82. doi: 10.1017/S0 007114507721487.

35. Levitan EB, Wolk A, Mittleman MA. Fatty fish, marine omega-3 fatty acids, and incidence of heart failure. Eur J Clin Nutr. 2010; 64(6):587-94. doi: 10.1038/ejcn.2010.50.

36. Bjerregaard $L$, Joensen AM, Dethlefsen $C$, Jensen MK, Johnsen SP, Tjønneland A, et al. Fish intake and acute coronary syndrome. Eur Heart J. 2010; 31:29-34. doi:10.1093/eurheartj/ehp375.

37. Berry JD, Prineas RJ, Horn LV, Passman R, Larson J, Goldberger J, et al. Dietary fish intake and incident atrial fibrillation (from the Women's Health Initiative). Am J Cardiol. 2010; 105(6):844-8. doi: 10.1016/j.amjcard.2009.11.039.

38. Hedelin $M$, Löf $M$, Olsson $M$, Lewander T, Nilsson $B$, Hultman CM, et al. Dietary intake of fish, omega3, omega-6 polyunsaturated fatty acids and vitamin $\mathrm{D}$ and the prevalence of psychotic-like symptoms in a cohort of 33000 women from the general population. BMC Psychiat. 2010; 10(38):1-13. doi: 10.1186/1471-244X-10-38.

39. Larsson SC, Virtamo J, Wolk A. Fish consumption and risk of stroke in Swedish women. Am J Clin Nutr. 2011; 93(3):487-93. doi: 10.3945/ajcn.110.0 02287.
40. Poudel-Tandukar K, Nanri A, Iwasaki M, Mizoue T, Matsushita $Y$, Takahashi $Y$, et al. Long chain n-3 fatty acids intake, sh consumption and suicide in a cohort of Japanese men and women: the Japan Public Health Center-based (JPHC) Prospective study. J Affective Disord. 2011; 129:282-8. doi: 1 0.1016/j.jad.2010.07.014.

41. World Health Organization. Global strategy on diet, physical activity and health: list of all documents and publications. Geneva: WHO; 2004.

42. American Cancer Society. ACS News Center [Internet]. [cited 2008 Jul 6]. Available from: <http:// www.cancer.org/docroot/NWS/content/update/ NWS_1_1xU_Increased_Fatty_Fish_Consumption_ May_Reduce_Prostate_Cancer_Risk.asp>.

43. Kim N-S, Lee B-K. Blood total mercury and fish consumption in the Korean general population in KNHANES III, 2005. Sci Total Environ. 2010; 408(20): 4841-7.

44. Benefice EA, Luna-Monrroy SAB, Lopez-Rodriguez RC. Fishing activity, health characteristics and mercury exposure of Amerindian women living alongside the Beni River (Amazonian Bolivia). Int J Hyg Environ Health. 2010; 213(6):458-64.

45. Domingo JL, Bocio A, Falcó G, Llobet JM. Benefits and risks of fish consumption. Part I. A quantitative analysis of the intake of omega-3 fatty acids and chemical contaminants. Toxicology. 2007; 230 (2-3):219-26. doi: 10.1016/j.tox.2006.11.054.

46. Foran JA, Good DH, Carpenter DO, Hamilton MC, Knuth BA, Schwager SJ. Quantitative analysis of the benefits and risks of consuming farmed and wild salmon. J Nutr. 2005; 135(11):2639-43.

47. Mahaffey KR, Clickner RP, Jeffries RA. Methylmercury and omega-3 fatty acids: co-occurrence of dietary sources with emphasis on fish and shellfish. Environ Res. 2007; 107(1):20-9. doi: 10.1 016/j.envres.200 7.09.011.

48. Wennberg M, Bergdahl IA, Stegmayr B, Hallmans G, Lundh T, Skerfving S, et al. Fish intake, mercury, long-chain $n-3$ polyunsaturated fatty acids and risk of stroke in Northern Sweden. Brit J Nutr. 2007; 98(5):1038-45. doi: 10.1017/S00071145077565 19.

49. Mozaffarian D, Shi P, Morris JS, Spiegelman D, Grandjean P, Siscovick DS, et al. Mercury exposure and risk of cardiovascular disease in two U.S. cohorts. N Engl J Med. 2001; 364(12):1116-25. doi: 10.1056/NEJMoa1006876. 


\section{ATTACHED}

STUDIES ON THE POTENTIAL BENEFITS OF FISH CONSUMPTION FOR THE HUMAN HEALTH, PUBLISHED BETWEEN 2003 AND 2011 , AND IDENTIFIED BY AUTHOR, COUNTRY, YEAR, STUDY TYPE, SAMPLE CHARACTERISTIC AND STUDY VARIABLES, STATISTICAL ANALYSIS AND THE MAIN RESULTS. FLORIANÓPOLIS (SC), BRAZIL, 2011

\begin{tabular}{|c|c|c|c|c|c|}
\hline $\begin{array}{l}\text { Author, year } \\
\text { country }\end{array}$ & $\begin{array}{c}\text { Size }(n) \text { and } \\
\text { sample characteristic }\end{array}$ & Study Variables & Statistical Analysis & Dietary methods & Results \\
\hline $\begin{array}{l}\text { Mozaffarian } \\
\text { et al. }(2003)^{9} \\
\text { USA }\end{array}$ & $\begin{array}{l}3,910 \text { Men and } \\
\text { women }>65 \text { years }\end{array}$ & $\begin{array}{l}\text { Fish Consumption } \\
\text { and way of prepa- } \\
\text { ration } \\
\text { Risk of IHD and } \\
\text { arrhythmia }\end{array}$ & $\begin{array}{l}\text { Cox proportional } \\
\text { Hazard Model; } \\
\text { probability ratio test }\end{array}$ & $\begin{array}{l}1 \text { semi-quantitative } \\
\text { food frequency } \\
\text { questionnaire, on } \\
\text { usual consumption, } \\
\text { validated* }\end{array}$ & $\begin{array}{l}\text { Consumption of grilled or } \\
\text { baked fish } \geq 3 \times \text { /week } \downarrow \text { death } \\
\text { risk for IHD or arrhythmia. } \\
\text { Fried fish or fish sandwich } \\
\uparrow \text { risk of these diseases }\end{array}$ \\
\hline $\begin{array}{l}\text { Augustsson } \\
\text { et al. }(2003)^{15} \\
\text { USA }\end{array}$ & $\begin{array}{l}\text { 47,882 Men 40-to } \\
\text { 75-year-old }\end{array}$ & $\begin{array}{l}\text { Fish consumption } \\
\text { Risk of prostate CA } \\
\text { Vasectomy historical } \\
\text { background }\end{array}$ & Logistic regression & $\begin{array}{l}3 \text { posted FFQ ( } t=0 \text {, } \\
t=4, t=8) \text { of } 1 \text { year, } \\
\text { semiquantitative, } \\
\text { validated }^{*}\end{array}$ & $\begin{array}{l}\text { Fish consumption }>3 \times / \text { week } \\
\downarrow \text { risk of prostate CA. } \\
\text { Ingestion of } 0.5 \mathrm{~g} \text { of fatty } \\
\text { acids/day from seafood } \downarrow \\
24 \% \text { risk of metastatic CA }\end{array}$ \\
\hline $\begin{array}{l}\text { Erkkilä et al. } \\
(2004)^{6} \\
\text { USA }\end{array}$ & $\begin{array}{l}229 \text { Postmenopausal } \\
\text { women 64/65 years } \\
\text { old (average) }\end{array}$ & $\begin{array}{l}\text { Fish consumption } \\
\text { Progression of } \\
\text { coronary disease }\end{array}$ & $\begin{array}{l}t \text { Test chi-squared } \\
\text { test; covariance } \\
\text { analysis; Spearman } \\
\text { correlation } \\
\text { coefficient }\end{array}$ & $\begin{array}{l}1 \text { semiquantitative } \\
\text { FFQ of } 1 \text { year, with } \\
126 \text { item ( } 3 \text { of fish) } \\
\text { validated }\end{array}$ & $\begin{array}{l}\text { Consumption of } \geq 2 \text { portions } \\
\text { of fish or } \geq 1 \text { portion/week } \\
\text { of tuna/dark meat fish } \downarrow \\
\text { stenosis in the diabetic } \\
\text { ones. Consumption } \geq 1 \\
\text { portion of fish/week } \downarrow \\
\text { progression of atherosclerosis } \\
\text { in women with CAD }\end{array}$ \\
\hline $\begin{array}{l}\text { Kalmijn } \\
\text { et al. }(2004)^{8} \\
\text { Holland }\end{array}$ & $\begin{array}{l}\text { 1,613 Men and } \\
\text { women } 45 \text {-to } \\
70 \text {-year-old }\end{array}$ & $\begin{array}{l}\text { Fish consumption } \\
\text { Assessment of the } \\
\text { cognitive function }\end{array}$ & $\begin{array}{l}\text { Logistic regression } \\
\text { analysis }\end{array}$ & $\begin{array}{l}1 \text { semiquantitative } \\
\text { FFQ of } 1 \text { year, with } \\
178 \text { items ( } 3 \text { of fish) } \\
\text { validated }\end{array}$ & $\begin{array}{l}\text { The increase of } 4 \mathrm{~g} / \text { day in fat } \\
\text { fish consumption was } \\
\text { associated with } \downarrow \text { risk of } \\
\text { damages in the cognitive } \\
\text { function }\end{array}$ \\
\hline $\begin{array}{l}\text { Timonen } \\
\text { et al. }(2004)^{12} \\
\text { Finland }\end{array}$ & 5689 Men and women & $\begin{array}{l}\text { Fish consumption } \\
\text { Risk of depression } \\
\text { and suicide ideas } \\
\text { Sex }\end{array}$ & $\begin{array}{l}\text { Logistic regression } \\
\text { analysis }\end{array}$ & $\begin{array}{l}1 \text { FFQ posted of } 6 \\
\text { months ( } 1 \text { of fish) } \\
\text { without validation } \\
\text { register }\end{array}$ & $\begin{array}{l}\text { Lower frequency in fish } \\
\text { consumption (rarely) was } \\
\text { associated with depression } \\
\text { in women, but not in men }\end{array}$ \\
\hline $\begin{array}{l}\text { Folsom \& } \\
\text { Demissie } \\
(2004)^{26} \\
\text { USA }\end{array}$ & $\begin{array}{l}4836 \\
\text { Postmenopausal } \\
\text { women, free of } \\
\text { cancer and CVD } \\
\text { 55-to 69-year-old }\end{array}$ & $\begin{array}{l}\text { Fish consumption } \\
\text { Risks of death by } \\
\text { CVD or stroke } \\
\text { Cancer incidence }\end{array}$ & $\begin{array}{l}\text { Covariance analysis; } \\
\text { poisson regression } \\
\text { model of relative risk }\end{array}$ & $\begin{array}{l}1 \text { posted semiquanti- } \\
\text { tative FFQ on usual } \\
\text { consumption with } \\
127 \text { item ( } 4 \text { of fish), } \\
\text { without a validation } \\
\text { register }\end{array}$ & $\begin{array}{l}\text { There was no association } \\
\text { between fish consumption } \\
\text { ( }<0.5 \geq 2.5 \text { portions/week) } \\
\text { and incidence of CA or risks } \\
\text { of death by CVD or CA }\end{array}$ \\
\hline $\begin{array}{l}\text { Hakkarainen } \\
\text { et al. }(2004)^{27} \\
\text { Finland }\end{array}$ & $\begin{array}{l}\text { 29,133 Men 50-to } \\
69 \text {-year- old }\end{array}$ & $\begin{array}{l}\text { Omega-3 and fish } \\
\text { consumption } \\
\text { Depression }\end{array}$ & $\begin{array}{l}\text { Cox proportional } \\
\text { Hazard Model }\end{array}$ & $\begin{array}{l}1 \text { semiquantitative } \\
\text { FFQ of } 1 \text { year } \\
\text { validated }^{*}\end{array}$ & $\begin{array}{l}\text { There was no association } \\
\text { between fish consumption } \\
\text { and depression (average of } \\
39.35 \mathrm{~g} / \text { day and } 39.62 \mathrm{~g} / \text { day } \\
\text { respectively among patients } \\
\text { with and without depression) }\end{array}$ \\
\hline $\begin{array}{l}\text { Mozaffarian } \\
\text { et al. }(2005)^{13} \\
\text { USA }\end{array}$ & $\begin{array}{l}\text { 4,775 Men and } \\
\text { women 65-to } \\
\text { 98-year-old }\end{array}$ & $\begin{array}{l}\text { Fish consumption } \\
\text { Way of preparation } \\
\text { Plasma levels of } \\
\text { omega-3 stroke } \\
\text { incidence }\end{array}$ & $\begin{array}{l}\text { Cox proportional } \\
\text { Hazard Model; } \\
\text { Kaplan-Meyer } \\
\text { survival method; } \\
\text { probability ratio test }\end{array}$ & $\begin{array}{l}1 \text { semiquantitative } \\
\text { FFQ of } 1 \text { year ( } 3 \text { items } \\
\text { of fish) validated }\end{array}$ & $\begin{array}{l}\text { Consumption of tuna or } \\
\text { other grilled/baked fish } \downarrow \\
\text { risk of ischemic stroke (1-4x/ } \\
\text { week and } \geq 5 x / \text { week). } \\
\text { Consumption }>1 x / \text { week of } \\
\text { fried fish/fish sandwiches } \uparrow \\
\text { risk of ischemic stroke }\end{array}$ \\
\hline
\end{tabular}


294 | AC FERNANDES et al.

ATTACHED

STUDIES ON THE POTENTIAL BENEFITS OF FISH CONSUMPTION FOR THE HUMAN HEALTH, PUBLISHED BETWEEN 2003 AND 2011, AND IDENTIFIED BY AUTHOR, COUNTRY, YEAR, STUDY TYPE, SAMPLE CHARACTERISTIC AND STUDY VARIABLES, STATISTICAL ANALYSIS AND THE MAIN RESULTS. FLORIANÓPOLIS (SC), BRAZIL, 2011

CONTINUATION

\begin{tabular}{|c|c|c|c|c|c|}
\hline $\begin{array}{l}\text { Author, year } \\
\text { country }\end{array}$ & $\begin{array}{c}\text { Size }(n) \text { and } \\
\text { sample characteristic }\end{array}$ & Study Variables & Statistical Analysis & Dietary methods & Results \\
\hline $\begin{array}{l}\text { Frost \& } \\
\text { Vestergaard } \\
(2005)^{28} \\
\text { Denmark }\end{array}$ & $\begin{array}{l}47,949 \text { men and } \\
\text { women } 50 \text {-to } \\
64 \text { year-old }\end{array}$ & $\begin{array}{l}\text { Omega-3 fish } \\
\text { consumption } \\
\text { Risk of atrial } \\
\text { fibrillation and/or } \\
\text { arrhythmia }\end{array}$ & $\begin{array}{l}\text { Spearman } \\
\text { correlation } \\
\text { coefficient }\end{array}$ & $\begin{array}{l}1 \text { self-managed } \\
\text { semiquantitative FFQ } \\
\text { on usual consumption } \\
\text { ( } 2 \text { items of fish) } \\
\text { validated }\end{array}$ & $\begin{array}{l}\text { Omega-3 fish consumption } \\
\text { (average } 0.16 \text { to } 1.29 \mathrm{~g} / \text { day) } \\
\text { and fish ( }<2 \mathrm{x} / \text { week to } \geq 2 \mathrm{x} \\
\text { week) was not associated } \\
\text { with } \downarrow \text { risk of atrial } \\
\text { fibrillation or arrhythmia }\end{array}$ \\
\hline $\begin{array}{l}\text { Lu et al. } \\
(2005)^{29} \text { USA }\end{array}$ & $\begin{array}{l}71,083 \text { women }>45 \\
\text { years-old }\end{array}$ & $\begin{array}{l}\text { Dietary } \\
\text { consumption } \\
\text { Cataract incidence }\end{array}$ & $\begin{array}{l}\text { Pearson and } \\
\text { Spearman } \\
\text { correlation } \\
\text { coefficient }\end{array}$ & $\begin{array}{l}5 \text { semiquantitative } \\
\text { FFQ ( } t=0, t=2, t=6, \\
t=10, t=14) \text { of } 1 \text { year } \\
\text { ( } 3 \text { items of fish) } \\
\text { validated }\end{array}$ & $\begin{array}{l}\text { Fish consumption } \geq 3 \times \text { / } \\
\text { week } \downarrow \text { risk ( } R R=0.89 \text { ) of } \\
\text { developing cataract } \\
\text { compared to those who } \\
\text { consumed fish } \leq 1 \times / \text { week } \\
(R R=1)\end{array}$ \\
\hline $\begin{array}{l}\text { Iso et al. } \\
(2006)^{7} \\
\text { Japan }\end{array}$ & $\begin{array}{l}41,578 \text { men and } \\
\text { women, free of CVD } \\
\text { or cancer } 40 \text {-to } \\
\text { 59-year-old }\end{array}$ & $\begin{array}{l}\text { Omega-3 and fish } \\
\text { consumption } \\
\text { Coronary disease }\end{array}$ & $\begin{array}{l}\text { Pearson correlation } \\
\text { coefficient; } \\
\text { Spearman } \\
\text { correlation } \\
\text { coefficient; (95\% } \\
\text { confidence interval) }\end{array}$ & $\begin{array}{l}2 \text { semiquantitative } \\
\text { FFQ ( } t=0, t=5) \text { of } 1 \\
\text { month and } 1 \text { year ( } 4 \\
\text { and } 19 \text { fish items) } \\
\text { validated }\end{array}$ & $\begin{array}{l}\text { High fish consumption ( } 8 \mathrm{x} / \\
\text { week or } 180 \mathrm{~g} / \text { day) } \downarrow \text { risk } \\
\text { of myocardial heart attack } \\
\text { and not-fatal coronary } \\
\text { disease, compared with a } \\
\text { meager consumption ( } 1 \mathrm{x} / \\
\text { week or } 23 \mathrm{~g} / \text { day) }\end{array}$ \\
\hline $\begin{array}{l}\text { Wolk et al. } \\
(2006)^{16} \\
\text { Sweden }\end{array}$ & $\begin{array}{l}61433 \text { women free of } \\
\text { cancer } 40 \text {-to } \\
76 \text {-year-old }\end{array}$ & $\begin{array}{l}\text { Consumption of fat } \\
\text { and lean fish } \\
\text { Renal cell } \\
\text { carcinoma }\end{array}$ & $\begin{array}{l}\text { Person-time, Cox } \\
\text { proportional Hazard } \\
\text { Model }(p<0.05)\end{array}$ & $\begin{array}{l}2 \text { semiquantitative } \\
\text { FFQ posted ( } t=0 \text { and } \\
t=10 \text { years) of } 1 \text { year } \\
\text { ( } t=0-67 \text { items; } t=10- \\
96 \text { items) validated }\end{array}$ & $\begin{array}{l}\text { Fat fish consumption } \geq 1 \times / \\
\text { month } \downarrow \text { risk of renal cell } \\
\text { cancer }\end{array}$ \\
\hline $\begin{array}{l}\text { Brouwer } \\
\text { et al. }(2006)^{30} \\
\text { Holland }\end{array}$ & $\begin{array}{l}5184 \text { men and } \\
\text { women, free of atrial } \\
\text { fibrillation } \geq 55 \text { years } \\
\text { of age }\end{array}$ & $\begin{array}{l}\text { Fish consumption } \\
\text { Incidence of atrial } \\
\text { fibrillation }\end{array}$ & $\begin{array}{l}\text { Cox proportional } \\
\text { Hazard Model (95\% } \\
\text { Cl) }\end{array}$ & $\begin{array}{l}1 \text { semiquantitative } \\
\text { FFQ of } 1 \text { year } \\
\text { validated, applied by } \\
\text { trained nutritionists. }\end{array}$ & $\begin{array}{l}\text { There was no association } \\
\text { between fish consumption } \\
\text { (average } 15.7 \mathrm{~g} / \text { day) and } \\
\text { atrial fibrillation incidence }\end{array}$ \\
\hline $\begin{array}{l}\text { Engeset } \\
\text { et al. }(2006)^{31} \\
\text { Norway }\end{array}$ & $\begin{array}{l}\text { 310,671 women } \\
25 \text {-to } 70 \text {-year-old }\end{array}$ & $\begin{array}{l}\text { Fish consumption } \\
\text { Risk of breast } \\
\text { cancer }\end{array}$ & $\begin{array}{l}\text { Cox proportional } \\
\text { Hazard Model ( } 95 \% \\
\text { Cl) }\end{array}$ & $\begin{array}{l}\text { Different types of } \\
\text { historical dietary } \\
\text { questionnaires and } \\
\text { semiquantitative FFQ } \\
\text { of } 1 \text { year (7 fish items) } \\
\text { validated }\end{array}$ & $\begin{array}{l}\text { There was no association } \\
\text { between fish consumption } \\
\text { (of } 5.54 \mathrm{~g} \text { to } 96.77 \mathrm{~g} / \text { day) } \\
\text { and risk of breast cancer } \\
\text { development }\end{array}$ \\
\hline $\begin{array}{l}\text { Koralek } \\
\text { et al. }(2006)^{32} \\
\text { USA }\end{array}$ & $\begin{array}{l}\text { 29,592 men 55-to } \\
\text { 74year-old }\end{array}$ & $\begin{array}{l}\text { Fish and fatty alpha } \\
\text { linoleic } \\
\text { consumption } \\
\text { Risk of prostate } \\
\text { cancer }\end{array}$ & $\begin{array}{l}\text { Coeficiente de cor- } \\
\text { relação de Pearson; } \\
\text { Pearson correlation } \\
\text { coefficient; Cox } \\
\text { proportional Hazard } \\
\text { Model }\end{array}$ & $\begin{array}{l}5 \text { semiquantitative } \\
\text { FFQ ( } t=0, t=1, t=2, \\
t=3, t=4) \text { of } 1 \text { year, } \\
\text { with } 137 \text { items ( } 6 \text { fish } \\
\text { items) without } \\
\text { validation register }\end{array}$ & $\begin{array}{l}\text { There was no association } \\
\text { between ALA total } \\
\text { consumption ( } 1.09 \mathrm{~g} \text { to } \\
1.75 \mathrm{~g} / \text { day) and of ALA in } \\
\text { fish, and risk of prostate } \\
\text { cancer }\end{array}$ \\
\hline $\begin{array}{l}\text { Myint } \\
\text { et al. } \\
(2006)^{33} \\
\text { England }\end{array}$ & $\begin{array}{l}24.312 \text { men and } \\
\text { women, with } \\
\text { historical background } \\
\text { of stroke } \\
\text { 40-79-year-old }\end{array}$ & $\begin{array}{l}\text { Fish consumption } \\
\text { stroke incidence } \\
\text { Arterial pressure } \\
\text { Blood tests (lipid } \\
\text { profile) }\end{array}$ & $\begin{array}{l}\text { Cox proportional } \\
\text { Hazard Model }\end{array}$ & $\begin{array}{l}1 \text { semiquantitative } \\
\text { FFQ of } 1 \text { year, with } \\
131 \text { items ( } 3 \text { fish } \\
\text { items) validation not } \\
\text { mentioned }\end{array}$ & $\begin{array}{l}\text { There was no association } \\
\text { between fish, crustaceans } \\
\text { or fish roe consumption and } \\
\text { risk of stroke incidence }\end{array}$ \\
\hline
\end{tabular}


ATTACHED

STUDIES ON THE POTENTIAL BENEFITS OF FISH CONSUMPTION FOR THE HUMAN HEALTH, PUBLISHED BETWEEN 2003 AND 2011, AND IDENTIFIED BY AUTHOR, COUNTRY, YEAR, STUDY TYPE, SAMPLE CHARACTERISTIC AND STUDY VARIABLES, STATISTICAL ANALYSIS AND THE MAIN RESULTS. FLORIANÓPOLIS (SC), BRAZIL, 2011

CONCLUSION

\begin{tabular}{|c|c|c|c|c|c|}
\hline $\begin{array}{l}\text { Author, year } \\
\text { country }\end{array}$ & $\begin{array}{c}\text { Size }(n) \text { and } \\
\text { sample characteristic }\end{array}$ & Study Variables & Statistical Analysis & Dietary methods & Results \\
\hline $\begin{array}{l}\text { Sanchez } \\
\text { Villegas } \\
\text { et al. (2007) } \\
\text { Spain }\end{array}$ & $\begin{array}{l}7903 \text { men and } \\
\text { women }\end{array}$ & $\begin{array}{l}\text { Omega-3 and fish } \\
\text { consumption } \\
\text { Mental disorders }\end{array}$ & $\begin{array}{l}\text { Non-conditional } \\
\text { logistic regression } \\
\text { analysis, linear } \\
\text { tendency } \\
\text { cross-sectional tests } \\
(p<0.05)\end{array}$ & $\begin{array}{l}2 \text { semiquantitative } \\
\text { FFQ posted ( } t=0 \text { and } \\
t=2 \text { years) of } 1 \text { year } \\
\text { (136 items) validated }\end{array}$ & $\begin{array}{l}\text { There was no association } \\
\text { between fish consumption } \\
\text { ( } 36.43 \mathrm{~g} \text { to } 161.90 \mathrm{~g} / \text { day) or } \\
\text { of omega-3 }(0.39 \mathrm{~g} \text { to } \\
1.89 \mathrm{~g} / \text { day) and risk of } \\
\text { mental disorders }\end{array}$ \\
\hline $\begin{array}{l}\text { Engeset } \\
\text { et al., }(2007)^{34} \\
\text { Norway }\end{array}$ & $\begin{array}{l}63914 \text { women } 40 \text {-to } \\
71 \text {-year-old }\end{array}$ & $\begin{array}{l}\text { Fish consumption } \\
\text { Colon cancer }\end{array}$ & $\begin{array}{l}\text { Cox Proportional } \\
\text { Hazard Model }\end{array}$ & $\begin{array}{l}1 \text { semiquantitative } \\
\text { FFQ posted of } 1 \text { year } \\
\text { (14 fish items) } \\
\text { validated }\end{array}$ & $\begin{array}{l}\text { There was no association } \\
\text { between fish consumption } \\
\text { ( } 46.2 \mathrm{~g} \text { to } 167.2 \mathrm{~g} / \text { day }) \text { and } \\
\text { a relative risk of colon } \\
\text { cancer }\end{array}$ \\
\hline $\begin{array}{l}\text { Steffen } \\
(2008)^{10} \text { USA }\end{array}$ & $\begin{array}{l}14962 \text { men and } \\
\text { women } 45 \text {-to } \\
\text { 64-year-old }\end{array}$ & $\begin{array}{l}\text { Dietary consumption } \\
\text { Venous } \\
\text { thromboembolism } \\
\text { incidence }\end{array}$ & $\begin{array}{l}\text { Spearman } \\
\text { correlation } \\
\text { coefficient } \\
(p<0.001)\end{array}$ & $\begin{array}{l}2 \text { semiquantitative } \\
\text { FFQ ( } t=6) \text { of } 1 \text { month } \\
\text { and } 1 \text { year ( } 66 \text { items) } \\
\text { validated }\end{array}$ & $\begin{array}{l}\text { Fish consumption } \geq 1 \times / \text { week } \\
\downarrow \text { risk of venous } \\
\text { thromboembolism } \\
\text { development }\end{array}$ \\
\hline $\begin{array}{l}\text { Levitan } \\
\text { et al. } \\
(2010)^{35} \text { USA }\end{array}$ & $\begin{array}{l}36234 \text { women } 48 \text {-to } \\
\text { 83-year-old }\end{array}$ & $\begin{array}{l}\text { Omega-3 and fish } \\
\text { consumption } \\
\text { Weak heart }\end{array}$ & $\begin{array}{l}\text { Cox Proportional } \\
\text { Hazard Model }(95 \% \\
\text { Cl) }\end{array}$ & $\begin{array}{l}1 \text { self-administered } \\
\text { FFQ of } 1 \text { year (96 item) } \\
\text { validated }\end{array}$ & $\begin{array}{l}\text { Moderate fish consumption } \\
\text { (1-2 portions/week) and } \\
\text { omega-3 was associated } \\
\text { with a lower number in } \\
\text { hospitalizations for weak } \\
\text { heart or death. }\end{array}$ \\
\hline $\begin{array}{l}\text { Bjerregaard } \\
\text { et al. }(2010)^{36} \\
\text { Denmark }\end{array}$ & $\begin{array}{l}57053 \text { men and } \\
\text { women } 50 \text {-to } \\
\text { 64-year-old }\end{array}$ & $\begin{array}{l}\text { Fat and lean fish } \\
\text { consumption Acute } \\
\text { coronary syndrome } \\
\text { (ACS) }\end{array}$ & $\begin{array}{l}\text { Cox Proportional } \\
\text { Hazard Model }(95 \% \\
\text { Cl) }\end{array}$ & $\begin{array}{l}1 \text { self-administered } \\
\text { semiquantitative } \mathrm{FFQ} \\
(t=0) \text { of } 1 \text { year ( } 14 \text { fish } \\
\text { items) validated }\end{array}$ & $\begin{array}{l}\text { Moderate consumption of } \\
\text { fat fish }(\geq 7 \mathrm{~g} / \text { day) was } \\
\text { associated with a lower risk } \\
\text { of ACS in men }\end{array}$ \\
\hline $\begin{array}{l}\text { Berry et al. } \\
(2010)^{37} \text { USA }\end{array}$ & $\begin{array}{l}44720 \\
\text { Postmenopausal } \\
\text { women 50-to } \\
79 \text {-year-old }\end{array}$ & $\begin{array}{l}\text { Fish consumption } \\
\text { Atrial fibrillation } \\
\text { incidence }\end{array}$ & $\begin{array}{l}\text { Multivariable logistic } \\
\text { regression analysis } \\
(p<0.05)\end{array}$ & $\begin{array}{l}1 \text { self-administered } \\
\text { semiquantitative FFQ } \\
(t=0) \text { of } 3 \text { months ( } 3 \\
\text { fish items) validated }\end{array}$ & $\begin{array}{l}\text { There was no association } \\
\text { between fish consumption } \\
\text { (average } 1.5 \text { portions of } \\
85 \mathrm{~g} / \text { week) and atrial } \\
\text { fibrillation incidence }\end{array}$ \\
\hline $\begin{array}{l}\text { Hedelin et al. } \\
(2010)^{38} \\
\text { Sweden }\end{array}$ & $\begin{array}{l}\text { 33,623 women } 30 \text {-to } \\
49 \text {-year-old }\end{array}$ & $\begin{array}{l}\text { Fish, omega-3 and } \\
\text { vitamin D } \\
\text { consumption } \\
\text { Psychotic } \\
\text { symptoms }\end{array}$ & $\begin{array}{l}\text { Multinomial logistic } \\
\text { regression (95\% IC) }\end{array}$ & $\begin{array}{l}1 \text { self-administered } \\
\text { FFQ of } 6 \text { months ( } 8 \\
\text { groups of food and } \\
\text { drinks) validated }\end{array}$ & $\begin{array}{l}\text { Risk of psychotic symptoms } \\
\text { was } 53 \% \text { lower with the } \\
\text { consumption of fish } 3-4 \\
\text { times/week compared to no } \\
\text { consumption at all. }\end{array}$ \\
\hline $\begin{array}{l}\text { Larsson } \\
\text { et al. }(2011)^{39} \\
\text { Sweden }\end{array}$ & $\begin{array}{l}\text { 34,670 women } 49 \text {-to } \\
83 \text {-year-old }\end{array}$ & $\begin{array}{l}\text { Fish consumption } \\
\text { stroke risk } \\
\text { Anthropometric } \\
\text { data }\end{array}$ & $\begin{array}{l}\text { Cox Proportional } \\
\text { Hazard Model }(95 \% \\
\text { CI) Multivariate } \\
\text { regression model }\end{array}$ & $\begin{array}{l}1 \text { self-administered } \\
\text { FFQ of } 1 \text { year ( } 76 \text { item) }\end{array}$ & $\begin{array}{l}\text { Fish consumption ( } \geq 3 \text { times/ } \\
\text { week), especially lean fish, } \\
\text { may reduce risk of stroke in } \\
\text { women }\end{array}$ \\
\hline $\begin{array}{l}\text { Poudel } \\
\text { Tandukar, } \\
\text { et al. }(2011)^{40} \\
\text { Japan }\end{array}$ & $\begin{array}{l}101,507 \text { men and } \\
\text { women } 40 \text {-to } \\
69 \text {-year-old }\end{array}$ & $\begin{array}{l}\text { Fish, EPA and DHA } \\
\text { consumption } \\
\text { Risk of suicide }\end{array}$ & $\begin{array}{l}\text { Cox Proportional } \\
\text { Hazard Model ( } 95 \% \\
\text { IC), Spearman } \\
\text { correlation } \\
\text { coefficient, residuals } \\
\text { from regressions, } \\
\text { multivariate model } \\
(p<0.05)\end{array}$ & $\begin{array}{l}1 \text { semiquantitative } \\
\text { self-administered FFQ } \\
\text { (19 fish items). No } \\
\text { validation mentioned }\end{array}$ & $\begin{array}{l}\text { High fish consumption } \\
(152.84 \mathrm{~g} / \text { day }) \text { was not } \\
\text { associated with lower risk of } \\
\text { suicide }\end{array}$ \\
\hline
\end{tabular}

* Items assessed in the food frequency questionnaires were not cited in the article.

Note: FFQ: Frequency Food Questionnaire; CA: Cancer; CVD: Cardiovascular Disease; CAD: Coronary Arterial Disease; CI: Confidence Interval; ALA: Alpha-Linolenic Acid; RR: Relative Risk; IHD: Ischemia Heart Disease; ACS: Acuté Corohary Syndrome; EPA: Eicosapentaenoic Acid Consumption; DHA: Docosahexaenoic Acid. 
